\title{
MENINGKATKAN TANGGUNG JAWAB BELAJAR MELALUI STRATEGI GIVING QUESTIONS AND GETTING ANSWERS PADA SISWA
}

\author{
Rodhiyah Syafitri ${ }^{1, *}$ \\ ${ }^{1}$ Universitas Pendidikan Ganesha
}

\begin{abstract}
Abstrak
Penelitian ini bertujuan untuk mengetahui peningkatan tanggung jawab belajar siswa melalui strategi giving questions and getting answers. Penelitian ini adalah penelitian tindakan kelas dengan subjek penelitian adalah siswa kelas III B SD Laboratorium Undiksha sebanyak 35 orang. Pengumpulan data dalam penelitian ini dilakukan dengan metode kuesioner. Data yang telah didapatkan selanjutnya dianalisis dengan menggunakan metode analisis deskriptif kuantitatif. Data hasil penelitian siklus I menunjukkan tanggung jawab belajar siswa secara klasikal mencapai 58,04\% pada kategori cukup tinggi. Pada siklus II secara klasikal mencapai 66,69\% pada kategori tinggi. Dengan demikian peningkatan tanggung jawab belajar siswa mencapai 8,65\%. Hasil penelitian ini menunjukkan bahwa tanggung jawab belajar siswa dapat meningkat melaui strategi giving questions and getting answers.
\end{abstract}

Kata-kata Kunci:

Strategi, giving, questions and getting answers, tanggung jawab belajar

\section{PENDAHULUAN}

Pendidikan karakter dalam kurikulum 2013 pada dasarnya bertujuan untuk membina karakter peserta didik menjadi lebih baik seperti mempunyai sikap kerjasama, bertanggung jawab, percaya diri, bersikap santun, kompetitif dan jujur sehingga mutu proses dan hasil pendidikan meningkat. Hal ini dibuktikan oleh Mulyasa (2013:7) dimana "pendidikan karakter dalam kurikulum 2013 bertujuan untuk meningkatkan mutu proses dan hasil pendidikan, yang mengarah pada pembentukan budi pekerti dan akhlak mulia peserta didik secara utuh, terpadu, seimbang sesuai dengan standar kompetensi lulusan pada setiap satuan pendidikan" melalui implementasi kurikulum 2013 yang berbasis karakter diharapkan peserta didik mampu secara mandiri meningkatkan dan menggunakan pengetahuannya, mengkaji dan menginternalisasi serta mempersonalisasi nilai nilai karakter dan akhlak mulia sehingga terwujud dalam perilaku sehari-hari.

Implementasi kurikulum 2013 yang berbasis karakter diharapkan peserta didik mampu secara mandiri meningkatkan dan menggunakan pengetahuannya, mengkaji dan menginternalisasi serta mempersonalisasi nilai nilai karakter dan akhlak mulia sehingga terwujud dalam perilaku sehari-hari.

Keberhasilan kurikulum 2013 dalam membina kompetensi dan karakter di sekolah dapat diketahui dari berbagai perilaku sehari-hari yang tampak dalam aktivitas siswa dan warga sekolah lain, perilaku tersebut diwujudkan dalam bentuk sikap kerjasama, bertanggung jawab, percaya diri, bersikap santun, kompetitif dan jujur. Siswa dituntut belajar aktif di setiap mata pelajaran yang diberikan guru akan memiliki pengetahuan luas serta siswa sendirilah yang harus bertanggung jawab dalam setiap proses belajar dan hasil belajar agar seimbang (Wahyudin,2002).

Pengertian nilai tanggung jawab Kemendiknas (2010:10) mendeskripsikan tanggung jawab sebagai sikap dan perilaku seseorang untuk melaksanakan tugas dan kewajibannya, yang seharusnya dia lakukan, terhadap diri sendiri, masyarakat, lingkungan (alam, sosial dan budaya), negara dan Tuhan Yang Maha Esa. Sedangkan Munir (2010:90) menyatakan bahwa tanggung jawab pada taraf yang paling rendah adalah kemampuan seseorang untuk menjalankan kewajiban karena dorongan dari dalam dirinnya. Tanggung jawab belajar, Menurut Lewis (2004:385) adalah kesediaan seseorang untuk mengerjakan tugas belajar dengan sebaik-baiknya dalam segala konsekuensi yang menyertainya. Orang yang bertanggung jawab memiliki keyakinan bahwa dirinya memiliki sesuatu yang berharga untuk diberikan kepada orang lain dan yakin bahwa orang lain mampu merasakan hal yang sama terhadap dirinya. 
Tanggung jawab dalam belajar adalah kewajiban untuk menyelesaikan tugas yang telah diterima secara tuntas melalui usaha yang maksimal serta berani menanggung segala akibatnya. Individu yang bertanggung jawab adalah individu yang dapat memenuhi tugas dan kebutuhan dirinya sendiri, serta dapat memenuhi tugas tanggung jawab terhadap lingkungan sekitarnya dengan baik. Pribadi harus dilatih secara terus-menerus, sehingga menjadi pribadi yang bertanggung jawab.

Listianti (2012:8) menyebutkan bahwa sikap tanggung jawab belajar meliputi sikap atau perilaku seseorang untuk melaksanakan tugas dan kewajibannya, yang seharusnya dia lakukan, terhadap dirinya sendiri maupun orang lain dan lingkungan sekitarnya. Indikator tanggung jawab menurut Fitri (2012:43) ada 4 yaitu sebagai berikut. 1) Mengerjakan tugas dan pekerjaan rumah dengan baik, 2) Bertanggung jawab terhadap setiap perbuatan, 3) Menyelesaikan tugas sesuai dengan jadwal yang telah ditentukan, 4) Mengerjakan tugas kelompok secara bersama-sama.

Dapat disimpulkan bahwa pendidikan karakter memiliki tujuan untuk memperbaiki sikap ataupun membiasakan siswa ntuk bertanggung jawab dengan setiap apa yang dilakukannya, karena pendidikan karakter akan lebih baik jika dilakukan sejak dini.

Tanggung jawab juga diartikan sebagai tugas yang mampu menyelaraskan dalam mencapai kompetensi siswa yang dimilikinya. Siswa yang tidak bertanggung jawab dalam belajar akan mendapatkan hasil yang kurang maksimal, sehingga siswa tidak dapat mengetahui seberapa besar hasil kemampuan dirinya. Guna mencapai cita-cita yang diinginkan sebagai seorang pelajar harus memiliki tanggung jawab yang penuh dalam segi belajarnya. Siswa yang memiliki rasa tanggung jawab belajar yang tinggi akan mencapai keinginan yang diinginkan.

Realitanya, siswa menginginkan sesuatu tanpa bersusah payah, ketika mendapatkan tugas dari guru dalam mengerjakan soal, bukannya mengerjakan tetapi siswa banyak yang mengeluh dan akhirnya siswa saling menukarkan pekerjaannnya dengan siswa lain. Tanggung jawab sebagian siswa tidak dilaksanakan dengan baik, maka dari itu sebagian besar siswa tidak mencapai hasil belajar yang memuaskan.

Berdasarkan observasi pada masa PPL PPG SM-3T bulan agustus 2017, yang dilaksanakan di kelas III B SD Lab Undiksha Singaraja diperoleh data sikap tanggung jawab belajar sebagai berikut, siswa yang menyelesaikan tugas tepat waktu $12,5 \%$, tidak putus asa dalam mengerjakan tugas $12,5 \%$, menyelesaikan tugas tepat waktu 15,62\%, mandiri (tidak menyontek) 12,5\%. Mengerjakan tugas rumah atau PR 31,25\%. dan wawancara dengan guru kelas III B SD Lab Undiksha Singaraja ditemukan beberapa masalah, antara lain; 1) Sering terjadi dalam suatu peristiwa belajar mengajar antara guru dan siswa tidak terhubung dengan baik, dimana guru asyik menjelaskan materi di depan kelas sementara beberapa siswa sibuk sendiri dengan kegiatannya misalnya melamun dan mengobrol 2) Pada saat proses belajar mengajar sebagian besar siswa tidak aktif dalam kegiatan diskusi kelompok. hanya ada beberapa siswa yang terlibat dalam mengerjakan tugas, 3) Kurangnya tanggung jawab antar siswa dengan kelompoknya sehingga hasil diskusi kurang memuaskan karena adanya mindset saling menggantungkan harapan kepada teman kelompok sehingga beberapa peserta didik terlihat acuh dan tidak peduli, 5) Siswa kurang memanfaatkan waktu belajar dengan baik dan benar.

Untuk mengatasi problematika tersebut guru harus bisa melakukan inovasi agar kegiatan belajar mengajar berjalan secara efektif, tidak membosankan, menyenangkan serta mampu mencapai tujuan pembelajaran yang optimal. Tujuan pembelajaran pada hakikatnya adalah perubahan perilaku siswa baik perubahan perilaku dalam bidang kognitif, afektif maupun psikomotorik. Permasalahan di atas dapat dilakukan perbaikan dengan menerapkan strategi giving questions and getting answers.

Menurut Zaini, dkk (2008:69) berpendapat bahwa strategi Giving Questions and Getting Answers sangat baik terutama untuk melibatkan peserta didik dalam mengulang materi yang telah disampaikan. Strategi Giving questions and Getting Answers (GQGA) adalah pembelajaran yang menggunakan dua buah kartu yang berupa kartu tanya dan kartu jawab yang masing-masing kartu hanya memiliki satu kesempatan untuk digunakan. Strategi Giving Questions and Getting Answers (GQGA) menurut Suprijono (2015:126) dikembangkan untuk melatih peserta didik memiliki kemampuan dan keterampilan bertanya dan menjawab pertanyaan. Strategi Giving questions and Getting Answers (GQGA) dalam pelaksanaan pembelajarannya dimulai dengan pemberian dua buah kartu untuk masing-masing siswa berupa kartu tanya digunakan untuk menulis pertanyaan dan kartu jawab untuk menulis jawaban pertanyaan, setiap kartu hanya memiliki satu kesempatan untuk menjawab dan bertanya. Setiap siswa diwajibkan untuk bertanya dan menjawab pertanyaan.

Kertas yang telah berisi pertanyaan dikumpulkan kepada guru, setelah kartu terkumpul guru memberikan kartu tanya secara acak guru menunjuk salah satu kelompok untuk membacakan kartu tanya yang didapat. Guru memberikan instruksi kepada siswa siapa yang dapat menjawab atau guru dapat menunjuk salah satu kelompok untuk menjawab pertanyaan yang dibacakan, siswa diharuskan menuliskan jawaban dari pertanyaan yang siswa jawab di kartu jawab kemudian dua buah kartu tanya 
dan kartu jawab diserahkan kepada guru, apabila dalam pelaksanaan pembelajaran siswa mengalami kebingungan dalam menjawab pertanyaan-pertanyaan yang ada, maka tugas guru membimbing dan mengarahkan siswa bertanya atau menjawab petanyaan.

Penggunaan strategi Giving Questions and Getting Answers sesuai dengan langkah menurut Zaini, dkk (2008:69) terdapat delapan langkah yaitu pembagian dua kartu indeks, melengkapi kalimat, pembentukan kelompok kecil, memilih pertanyaan-pertanyaan yang ada (kartu 1) dan topik-topik yang telah diseleksi, pembacaan pertanyaan-pertanyaan dari kartu 1 yang telah diseleksi, menjawab pertanyaan jika tidak ada yang bisa guru membantu menjawab pertanyaan, menyampaikan topik yang dapat dijelaskan dari kartu 2 kepada peserta didik lainnya, dan merangkum hasil diskusi.

Hamruni (2012:171) Strategi Giving questions and Getting Answers (GQGA) memiliki langkahlangkah yang harus dilakukan guru dalam proses pembelajaran adalah sebagai berikut.

1) Berikan dua kartu indeks kepada setip siswa

2) Mintalah setiap siswa menyelesaikan kalimat berikut ini:

a) Kartu 1: saya mempunyai pertanyaan tentang .....

b) Kartu 2: saya dapat jawaban tentang.....

3) Guru membuat sub kelompok dan minta masing-masingkelompokmemilih "pertanyaan untuk menjawab" yang paling menarik dari kartu-kartu anggota kelompoknya.

4) Guru meminta setiap kelompok melaporkan pertanyaan yang ia pilih Tentukan apakah seseorang dalam seluruh kelas dapat menjawab pertanyaan itu. Jika tidak, pengajar seharusnya merespons.

5) Guru meminta setiap sub kelompok untuk berbagi "pertanyaan untuk dijawab" yang ia pilih. Perintah anggota sub kelompok berbagi jawaban dengan kelompok lain.

Dari langkah-langkah di atas maka dapat disimpulkan berupa langkah-langkah yang akan dilakukan oleh guru untuk meningkatkan tanggung jawab belajar siswa adalah sebagai berikut.

1) Guru membagikan dua kartu yaitu kartu tanya dan kartu jawab, kartu tanya yaitu kartu yang nantinya akan digunakan untuk mencatat pertanyaan yang akan siswa ajukan, sedangkan kartu jawab digunakan untuk menulis jawaban yang terkait dengan pertanyaan yang dapat siswa jawab.

2) Guru membagi siswa dalam kelompok-kelompok, masing-masing kelompok terdiri dari empat sampai lima siswa.

3) Guru memberitahukan aturannya bahwa dua buah kartu tersebut masing-masing hanya dapat digunakan satu kali saja.

4) Mintalah setiap siswa menyelesaikan kalimat berikut ini:

a) Kartu 1: saya mempunyai pertanyaan tentang ....

b) Kartu 2: saya dapat menjawab tentang .....

5) Siswa diminta untuk mengisi identitas di dua kartu tersebut.

6) Guru menjelaskan materi ajar yang akan dibahas. Guru meminta siswa untuk

7) Guru membagikan secara acak kartu tanya yang telah dikumpulkan.

8) Guru menunjuk salah satu kelompok untuk membaca kartu tanya yang dipilih, kelompok lain mendengarkan.

9) Guru memberikan instruksi siapa yang dapat menjawab pertanyaan yang telah dibacakan ata dapat menunjuk langsung salah satu kelompok untuk menjawabnya.

10) Ketika ada siswa yang menjawab pertanyaan yang telah disampaikan dan menuliskannya dalam kartu tanya dan berbagi jawaban dengan kelompok lain maka kartu dikumpulkan kepada guru beserta kartu tanya yang tadi dibacakan, begitu seterusnya.

\section{METODE PENELITIAN}

Penelitian ini dirancang dalam bentuk penelitian tindakan kelas. Penelitian tindakan kelas merupakan prosedur penelitian di kelas yang dirancang untuk menanggulangi masalah nyata yang dialami guru berkaitan dengan siswa di kelas itu (Santyasa, 2007). Penelitian ini dirancang sampai siklus ke-N. Dalam penelitian tindakan kelas (PTK) ini mengacu pada teori yang dikemukakan Kemmis dan McTaggrat (Agung, 2010:91). Model penelitian ini terdapat empat tahapan pada satu siklus penelitian. Empat tahapan tersebut terdiri dari: perencanaan, tindakan, observasi/evaluasi dan refleksi. Subjek dalam penelitian ini adalah siswa kelas III B membuat pertanyaan dan mencatat pertanyaan pada kartu tanya masing-masing, guru memberi instruksi kartu untuk dikumpulkan kepada guru.

Strategi Giving Question and Getting Answer (GQGA) merupakan stratetegi pembelajaran yang dapat merangsang, memancing serta mengajak peserta didik untuk ikut berpartisifasi aktif. Strategi pembelajaran ini dikembangkan untuk melatih siswa memiliki kemampuan dan keterampilan bertanya dan menjawab pertanyaan sehingga materi yang tidak dimengerti oleh siswa dapat dengan mudah 
dimengerti. Sehingga apabila diberikan tugas, siswa dapat menyelesaikan tugas secara mandiri dan penuh tanggung jawab.

SD Lab Undiksha yang berjumlah 35 orang. Variabel terikat yang menjadi fokus perhatian dalam penelitian ini yaitu tanggung jawab belajar siswa. Untuk mengumpulkan data dalam penelitian ini digunakan metode non tes berupa kuesioner.

Metode kuesioner adalah suatu metode pengumpulan data yang dilakukan dengan jalan mengajukan suatu daftar pertanyaan tertulis kepada sejumlah individu, dan individu-individu yang diberikan jawaban secara tertulis pula (Nurkancana, 1993:45). Suyanto (2005:61) menyatakan bahwa kuesioner adalah daftar pernyataan terstruktur dengan alternatif jawaban yang telah tersedia sehingga responden tinggal memilih jawaban sesuai dengan aspirasi, persepsi, sikap, keadaan dan pendapat pribadinya.

Kuesioner yang disusun mengacu pada indikator tanggung jawab belajar siswa. Indikator tersebut yakni, a) menggunakan waktu secara efektif, b) melakukan persiapan sebelum pembelajaran, c) melaksanakan tugas individu yang diterima, d) melaksanakan proses diskusi, e) mengerjakan soal atau permasalahan dengan teliti. Data yang dihasilkan berupa rubrik penilaian bersifat interval (skor).

Kuesioner digunakan sebelum pemberian tindakan (prasiklus) dengan tujuan untuk mengetahui peserta didik yang memiliki tanggung jawab belajar yang rendah, dan digunakan pula diakhir siklus (tahap evaluasi) sehingga dapat mengetahui perubahan yang dialami oleh siswa setelah diterapkan strategi Giving Questions and Getting Answers (GQGA).

Kuesioner ini menggunakan skala likert yaitu lembar kuesioner skala lima. Alternatif jawaban ada 5 dengan kategori jawaban Sangat Sering (SS), Sering (S), Cukup Sering (CS), Jarang (J), dan Tidak Pernah (TP). Cara pengisian lembar kuesioner tanggung jawab belajar ini dengan tanda $(\sqrt{ })$ pada salah satu kolom alternatif jawaban yang paling sesuai dengan pilihan siswa (responsden).

Sedangkan cara pemberian skor terhadap jawaban responden adalah sebagai berikut: untuk pernyataan yang mendukung indikator (favorable), jika responden menjawab Sangat Sering (SS) diberi skor 5, Sering (S) diberi skor 4, Cukup Sering (CS) diberi skor 3, Jarang (J) diberi skor 2 dan Tidak Pernah (TP) diberi skor 1 . Sebaliknya, pada pernyataan yang tidak mendukung (unfavorable), apabila responden menjawab Sangat Sering (SS) diberi skor 1, Sering (S) diberi skor 2, Cukup

\section{HASIL DAN PEMBAHASAN}

Berdasarkan hasil analisis data siklus I, maka tingkat tanggung jawab belajar siswa secara klasikal dalam muatan Sering (CS) diberi skor 3, Jarang (J) diberi skor 4, dan Tidak Pernah (TP) diberi skor 5. Deskripsi data yang diperoleh akan dicari arah kecenderungannya dengan membandingkan mean kuesioner dengan mean ideal. Formula yang digunakan sebagai berikut.

$\mathrm{Mi}=1 / 2($ skor tertinggi ideal + skor
terendah ideal $)$
$\mathrm{SDi}=1 / 6$ (skor tertinggi ideal - skor
terendah ideal)

(Nurkancana, Sunartana, 1992)

Kuesioner yang disebarkan terdiri dari 25 item pernyataan. Cara penskoran terhadap butir jawaban responden adalah jika butir pernyataannya mendukung indikator (favorable) maka skor setiap butir adalah 5 sampai 1 , sedangkan jika butir pernyataannya tidak mendukung indikator (unfavorable) maka rentangan skor adalah 1 sampai 5.

Untuk mendapatkan kualifikasi skor tanggung jawab belajar, maka Mean ideal (Mi) dan Standar Deviasi ideal (SDi) harus ditetapkan terlebih dahulu. Berdasarkan pada kuesioner tersebut, maka skor maksimal idealnya adalah 125 dan skor minimal ideal adalah 25. Dari hasil analisis, maka diperolehlah Mean ideal (Mi) dan Standar Deviasi ideal (SDi) yaitu.

$$
\begin{aligned}
& \mathrm{MI}=\frac{1}{2}(125+25)=75 \\
& \mathrm{SDi}=\frac{1}{6}(125-25)=16,67
\end{aligned}
$$

Adapun kriteria keberhasilan penilaian didalam penelitian tindakan kelas ini adalah dengan melihat hasil rekap dari kuesioner tanggung jawab yang diberikan diakhir siklus. Penelitian tindakan kelas ini dikatakan berhasil apabila kualifikasi skor tanggung jawab belajar berada dalam kategori tinggi dan 
sangat tinggi dengan rentang skor berada diantara 83 - 125. pembelajaran dapat ditentukan dengan rumus sebagai berikut.

$$
\begin{aligned}
\text { Rata-rata }(\mathrm{M}) & =\frac{\sum X}{N} \\
\mathrm{M} & = \\
\mathrm{M} & =72,55
\end{aligned}
$$

Berdasarkan analisis di atas maka skor rata-rata tanggung jawab belajar siswa secara klasikal mencapai 72,55 dengan skor perolehan 2539,2. Kemudian hasil rata-rata tersebut dihitung ke dalam M\% sebagai berikut.

$$
\begin{aligned}
& \mathrm{M} \% \text { ? } \overline{\mathrm{SMI}} \overline{\mathrm{M}} \text { ? } 100 \% \\
& \mathrm{M} \%=\frac{72.55}{125} 100 \%
\end{aligned}
$$

Presentase tanggung jawab belajar siswa kelas III B SD Lab Undiksha adalah 58,04\%, dan apabila dikonversikan ke dalam PAP skala lima untuk kriteria tanggung jawab belajar siswa secara klasikal maka tanggung jawab belajar siswa untuk siklus I tergolong cukup tinggi. Kriteria penggolongan tanggung jawab belajar siswa, ditetapkan berdasarkan lima jenjang kategori seperti tabel di bawah ini:

$$
\mathrm{M} \%=58,04 \%
$$

Tabel 1. Kualifikasi Skor Tanggung Jawab Belajar Siswa

\begin{tabular}{ccc}
\hline NO & SKOR & KUALIFIKASI \\
\hline 1 & $\mathrm{Mi}+1,5 \mathrm{SDi} \leq X$ & Sangat tinggi \\
2 & $\mathrm{Mi}+0,5 \mathrm{SDi} \leq \mathrm{Mi}+1,5 \mathrm{SDi}$ & Tinggi \\
3 & $\mathrm{Mi}-0,5 \mathrm{SDi} \leq \mathrm{Mi}+0,5 \mathrm{SDi}$ & Cukup Tinggi \\
4 & $\mathrm{Mi}-1,5 \mathrm{SDi} \leq \mathrm{Mi}-0,5 \mathrm{SDi}$ & Rendah \\
5 & $\bar{X}<\mathrm{Mi}-1,5 \mathrm{SDi}$ & Sangat rendah \\
\hline
\end{tabular}

(Nurkancana, Sunartana, 1992)

Untuk mendapatkan kualifikasi skor tanggung jawab belajar, maka Mean ideal (Mi) dan Standar Deviasi ideal (SDi) harus ditetapkan terlebih dahulu. Berdasarkan pada kuesioner tersebut, maka skor maksimal idealnya adalah 125 dan skor minimal ideal adalah 25. Dari hasil analisis, maka diperolehlah Mean ideal (Mi) dan Standar Deviasi ideal (SDi) yaitu.

$$
\begin{aligned}
& \mathrm{MI}=\frac{\frac{1}{2}}{2}(125+25)=75 \\
& \mathrm{SDi}=\frac{1}{6}(125-25)=16,67
\end{aligned}
$$

Tabel 2. Kualifikasi Skor Tanggung Jawab Belajar Siswa

\begin{tabular}{ccc} 
NO & SKOR & KUALIFIKASI \\
\hline 1 & $100-125$ & Sangat tinggi \\
2 & $83-99$ & Tinggi \\
3 & $66-82$ & Cukup Tinggi \\
4 & $49-65$ & Rendah \\
5 & $0-48$ & Sangat rendah \\
\hline
\end{tabular}

Apabila analisis rata-rata (Mean) secara klasikal telah dilakukan, maka akan dilanjutkan menganalisis tinggi rendahnya tanggung jawab belajar siswa yang dikonversikan ke dalam Penilaian Acuan Patokan (PAP) sekala lima. 


\section{Tabel 3. Pedoman Konversi PAP Skala Lima tentang TingkatanTanggung Jawab Belajar}

\begin{tabular}{|c|c|c|}
\hline \multirow[t]{2}{*}{ NO } & Persentase & Kriteria Tanggung Jawab \\
\hline & & Belajar \\
\hline 1 & $80-100$ & Sangat tinggi \\
\hline 2 & $66,66-79$ & Tinggi \\
\hline 3 & $53,33-66,65$ & Cukup Tinggi \\
\hline 4 & $40,0-53,32$ & Rendah \\
\hline 5 & $0-39,99$ & Sangat rendah \\
\hline
\end{tabular}

(Nurkancana, Sunartana, 1992)

Berdasarkan hasil analisis data siklus II, maka tingkat tanggung jawab belajar siswa secara klasikal dalam muatan pembelajaran dapat ditentukan dengan rumus sebagai berikut.

$$
\begin{aligned}
\text { Rata-rata }(\mathrm{M})= & \frac{\frac{\sum X}{N}}{2917.6} \\
\mathrm{M} & = \\
\mathrm{M} & =83,36
\end{aligned}
$$

Berdasarkan analisis di atas maka skor rata-rata tanggung jawab belajar siswa secara klasikal mencapai 83,69 dengan skor perolehan 2917,6. Kemudian hasil rata-rata tersebut dihitung ke dalam M\% sebagai berikut. M\% ? sMI $^{\mathrm{M}}$ ? $100 \%$

$$
\mathrm{M} \%=\frac{83.36}{125} 100 \% \quad \mathrm{M} \%=66,69 \%
$$

Persentase tanggung jawab belajar siswa adalah 66,69\%, dan apabila dikonversikan ke dalam PAP skala lima untuk kriteria tanggung jawab belajar siswa secara klasikal maka tanggung jawab belajar siswa untuk siklus II tergolong tinggi.

Penelitan ini dilaksanakan di SD Lab Undiksha Singaraja pada siswa kelas III B, dengan banyak siswa adalah 35 siswa. Pada penelitian ini yang diukur adalah tanggung jawab belajar melalui strategi Giving Questions and Getting Answers (GQGA). Penelitian ini dirancang melalui beberapa siklus hingga menemukan tindakan yang terbaik. Pada siklus I terdiri dari perencanaan, pelaksanaan, observasi atau evaluasi dan refleksi siklus I, apabila belum berhasil akan dilanjutkan ke siklus II yang terdiri perencanaan, pelaksanaan, observasi atau evaluasi dan refleksi siklus II, apabila berhasil maka penelitian akan dihentikan karena telah mencapai target yang ditentukan.

Hasil penelitian menunjukkan tanggung jawab belajar siswa pada siklus I belum mencapai kriteria keberhasilan yaitu masih ada beberapa siswa secara individu yang memiliki tanggung jawab belajar pada kategori rendah walaupun secara klasikal rata-rata tanggung jawab belajar seluruh siswa sudah pada kategori tinggi. Hal ini di sebabkan karena ada beberapa siswa yang kurang memperhatikan guru ketika proses pembelajaran berlangsung sehingga minat belajar siswa belum mencapai kriteria keberhasilan yang ditentukan dalam penelitian ini. Maka dari itu segala upaya dirancang untuk menanggulangi kelemahan pada siklus I dan selanjutnya akan dilaksanakan pada siklus II. Pada siklus II ini segala yang dirancang dan diupayakan berjalan dengan lancar sehingga pada siklus II ini terjadi peningkatan tanggung jawab belajar siswa.

Berdasarkan analisis siklus I yaitu persentase tanggung jawab belajar siswa mencapai 58,04\% pada kategori tanggung jawab tinggi namun masih ada beberapa siswa yang masih berada pada kategori tanggung jawab cukup. Sedangkan pada siklus II mencapai 66,69\% pada kategori tanggung jawab belajar tinggi, selain itu seluruh siswa sudah berada pada kategori tanggung jawab belajar cukup tinggi dan tinggi. Hal ini menunjukkan terjadi peningkatan sebesar 8,65\% dari siklus I ke siklus II dan terjadi peningkatan tanggung jawab belajar secara individu maupun secara rata-rata klasikal secara keseluruhan. Secara 
umum penelitian ini dapat dikatakan berhasil, karena mampu meningkatkan tanggung jawab belajar pada siswa kelas III B SD Lab Undiksha.

\section{KESIMPULAN}

Berdasarkan hasil penelitian dan pembahasan yang telah diuraikan, dapat disimpulkan bahwa strategi Giving Questions and Getting Answers (GQGA) dapat meningkatkan tanggung jawab belajar siswa di kelas III B semester ganjil SD Lab Undiksha. Hal ini dapat dilihat dari meningkatnya tanggung jawab belajar siswa pada siklus I yang mencapai 58,04\% pada kategori tanggung jawab cukup tinggi namun masih ada beberapa siswa yang masih berada pada kategori tanggung jawab rendah. Sedangkan pada siklus II mencapai 66,69\% pada kategori tanggung jawab tinggi, selain itu seluruh siswa sudah berada pada kategori tanggung jawab belajar cukup tinggi dan tinggi. Hal ini menunjukkan terjadi peningkatan sebesar 8,65\% dari siklus I ke siklus II dan terjadi peningkatan tanggung jawab belajar secara individu maupun secara rata-rata klasikal secara keseluruhan.

\section{DAFTAR PUSTAKA}

Agung, A. A. Gede. 2010. Metodologi Penelitian Pendidikan. Singaraja: FIP Undiksha.

Bagong, Suyanto dan Sutinah. 2007. Metode Penelitian Sosial: Berbagai Alternatif Pendekatan. Jakarta: Kencana.

Endang Listiani. Jenis-Jenis Penilaian Dalam Evaluasi Pendidikan. https://www.academia.edu/5016631/je nisjenis-penilaian-dalam-evaluasi-pendidikan (online) diakses tanggal 01 Oktober 2017.

Hamruni, Strategi dan Model-model Pembelajaran Aktif Menyenangkan. Yogyakarta: Fakultas Tarbiyah UIN Sunan Kalijaga, 2009.

Hisyam Zaini, dkk., Strategi Pembelajaran Aktif. Yogyakarta: Pustaka Insan Madani, 2008.

Hollingsworth, P. Dan Lewis,G. (2008). Pembelajaran aktif:meningkatkan keasyikan kegiatan di kelas.Jakarta: PT. Indeks.

Mulyasa. 2014. Manajemen Pendidikan Karakter.Jakarta : Bumi Aksara.

Nurkancana, Wayan dan Sunartana. 2006. Evaluasi Hasil Belajar. Surabaya: Usaha Nasional. Sekretariat Direktoral Jendral Pendidikan

Dasar Kementerian Pendidikan Nasional. 2011. Mencari Karakter Terbaik dari Belajar Sejarah. Jakarta: Kementerian Pendidikan Nasional. Sekretariat Direktoral Jendral Pendidikan

Dasar Kementerian Pendidikan Nasional. 2011. Pendidikan Karakter dalam Pembelajaran PKn. Jakarta: Kementerian Pendidikan Nasional.

Suprijono, Agus. 2009.Cooperatif Learning.

Yogyakarta : Pustaka Belajar. Suprijono, Agus. 2011. Cooperative Learning

(Teori \& Aplikasi PAIKEM). Yogyakarta: Pustaka Pelajar.

Santyasa, W. 2007. Metodologi Penelitian Tindakan Kelas. (Makalah) Disajikan dalam Workshop tentang Penelitian Tindakan Kelas (PTK) bagi Para Guru SMP 2 dan 5 Nusa Penida Klungkung, pada tanggal 30 Nopember s.d 1 Desember 2007 di Nusa Penida. Singaraja: Universitas Pendidikan Ganesha.

Wahyudin, dkk (2006: hlm 123).Bahan Belajar Mandiri Evaluasi Pembelajaran SD. Jakarta: Kencana. 